\title{
Reaksi Pasar Modal Index LQ45, Index Consumer Goods, Index Manufacture dan Index Finance pada Peristiwa Pandemi Covid-19 April 2020 di Indonesia
}

\section{Zulfitra, Muliahadi Tumanggor}

Staf Pengajar Fakultas Ekonomi Universitas Pamulang

Email: zulfitra.dosen@gmail.com, dosen00871@unpma.ac.id

\begin{abstract}
ABSTRAK
Pandemi Global Virus Corona (Covid-19) telah mewabah di seluruh dunia. Di Indonesia dan hampir semua negara di dunia telah mengurangi aktifitas ekonominya, akibat adanya pandemi global ini. Peneliti menguji dampak pandemi Covid-19 di Indonesia, khususnya Pasar Modal pada Index LQ45, Index Consumer Goods, Index Manufacture dan Index Finance Bursa Efek Indonesia. Sample diambil pada masing-masing index, yaitu harga saham dan likuiditas saham, selama 13 hari pengamatan di bulan April 2020 yang dibandingkan dengan tahun sebelumnya. Metode penelitian menggunakan Event Study dengan Least Square Regression. Hasil penelitian menunjukkan bahwa peristiwa pandemi Covid-19 berdampak signifikan pada harga saham Index LQ45, Index Consumer Goods, Index Manufacture dan Index Finance. Sedangkan pada likuditas saham peristiwa pandemi Covid-19 hanya berdampak signifikan pada Index Consumer Goods dan Index Manufacture.
\end{abstract}

Kata kunci: Likuidtas Saham, Harga Saham, Corona (Covid-19)

\begin{abstract}
The Corona Global Pandemic Virus (Covid-19) has become a worldwide epidemic. In Indonesia and almost all countries in the world have reduced their economic activities, due to this global pandemic. Researchers examined the impact of the Covid-19 pandemic in Indonesia, particularly the Capital Market, on the LQ45 Index, Consumer Goods Index, Manufacture Index and Financial Index of the Indonesia Stock Exchange. Samples were taken on each index, namely stock prices and stock liquidity, for 13 days of observation in April 2020 compared to the previous year. The research method uses Event Study with Least Square Regression. The results showed that the Covid-19 pandemic event had a significant impact on the LQ45 Index, Consumer Goods Index, Manufacture Index and Finance Index. Whereas the liquidity of the Covid-19 pandemic events only had a significant impact on the Consumer Goods Index and the Manufacture Index.
\end{abstract}

Keywords: Stock Liquidity, Stock Prices, Corona (Covid-19).

\section{PENDAHULUAN}

\section{A. Latar Belakang}

Dalam investasi pasar modal, ketersediaan informasi menjadi pertimbangan khusus bagi investor. Harga pasar saham yang terjadi merupakan cerminan dari semua informasi yang tersedia (Fama, 1970). 
Informasi ini digunakan sebagai dasar pengambilan keputusan investasi. Informasi yang diperlukan investor secara umum berkaitan dengan mikroekonomi perusahaan seperti kinerja keuangan perusahaan, aksi koorporasi dan lainnya. Informasi selanjutnya yang diperlukan investor berkaitan dengan makroekonomi seperti tingkat suku bunga, inflasi, nilai tukar mata uang dan lainnya. Selain itu terdapat pula informasi diluar mikroekonomi dan makroekonomi, seperti peristiwaperistiwa yang secara langsung maupun tidak langsung yang berdampak ke pasar modal. Beberapa persitiwa seperti serangan bom yang berdampak terhadap pasar modal dijelaskan oleh Utama \& Hapsari (2012), dan Drakos (2004). Selain serangan bom teroris beberapa peristiwa seperti virus SARS di Taiwan tahun 2003 (Chen, et al 2009). Kemudian epidemic SARS yang berdampak pada bursa saham asia (Chen, et al 2018).

Setelah wabah SARS, kemudian terjadi lagi wabah penyakit yaitu
Corona Virus Covid-19 di awal tahun 2020 ini. Wabah Covid-19 in telah masuk di berbagai negara seperti China, Amerika, Prancis, Inggris, Spanyol, Italia, Asia Tenggara dan lain-lain. Wabah penyakit corona covid-19 juga masuk ke Indonesia di kisaran awal tahun 2020, telah berdampak kelumpuhan ekonomi, yang berimbas pada pasar modal. Bursa Efek Indonesia (BEI) sebagai satu-satunya pasar modal yang ada di Indonesia juga terkena imbas dari covid-19. Peneliti mencoba mengkaji secara empiris adanya dampak epidemi Corono Covid-19 pada Bursa Efek Indonesia. Peneliti mencoba mengujinya pada beberapa IndexIndex yang ada di Bursa Efek Indonesia. Adapun index yang dikaji yaitu: Index LQ45, Index Consumer Goods, Index Manufacture dan Index Finance.

Peneliti berharap temuan hasil penelitian dapat bermanfaat bagi praktisi, investor dan perusahaan, serta menjadi kontribusi bagi ilmu pengetahuan khususnya Teori Efisiensi 
Pasar yang pertama kali dikembangkan oleh Fama (1970).

\section{TINJAUAN PUSTAKA}

\section{A. Teori dan Penelitian Terdahulu}

Sejak teori efisiensi pasar dikemukakan pertama kali oleh Fama (1970) teori ini terus berkembang dan masih dapat digunakan hingga saat ini terutama pada peristiwa-peristiwa yang berdampak ke pasar modal, dampak peristiwa-peristiwa ini dapat diukur dengan metode event study. Adapun teori efisiensi pasar yang dikaji adalah Efisensi Pasar bentuk setengah kuat atau dikenal dengan Semi Strong Form. Dimana dalam teori ini informasi yang dipulikasi menimbulkan reaksi pada pasar modal.

Beberapa penelitian terdahulu yang mengkaji hubungan peristiwa wabah virus corona dengan pasar saham diantaranya dijelaskan oleh Nippani \& Washer (2004), yang membandingkan kinerja indeks pasar saham pada periode sebelum timbulnya SARS dan pada periode tersebut ketika negara dipengaruhi oleh penyakit SARS ini. Studi Nippani \& Washer (2004) mereka membandingkan rata-rata harian dan return median di seluruh sub-periode pra-SARS dan yang terkena dampak SARS, dan menemukan bahwa SARS memberikan dampak negatif signifikan pada bursa saham Cina dan Vietnam, tetapi bukan pada bursa saham Kanada, Hong Kong, Indonesia, Filipina, Singapore.

Penelitian selanjutnya dilakukan Loh (2006) yang menguji dampak penyakit SARS pada saham-saham perusahaan penerbangan di negara Canada, China, Hongkong, Singapore dan Thailand. Dimana dalam hasil penelitian Loh (2006) ditemukan bahwa saham-saham perusahaan penerbangan lebih sensitive pengaruhnya akibat penyakit SARS dibandingkan dengan saham-saham perusahaan non penerbangan.

Kemudian Chen et al (2007) yang meneliti wabah sindrom pernafasan akut (SARS) yang parah pada tahun 2003 melemahkan ekonomi Taiwan. Industri pariwisata paling menderita, mengalami penurunan harga saham terendah (sekitar 29 persen) dalam waktu satu bulan setelah wabah SARS. Penelitian ini menguji efeknya epidemi SARS 
pada pergerakan harga saham hotel Taiwan menggunakan pendekatan event study. Tujuh perusahaan hotel yang diperdagangkan secara umum mengalami penurunan harga saham yang tajam selama periode wabah SARS. Pada dan setelah hari wabah SARS, harga saham hotel-hotel Taiwan menyediakan menunjukkan return abnormal rata-rata kumulatif negatif signifikan, yang menunjukkan dampak signifikan wabah SARS pada kinerja harga saham perhotelan.

Chen et al (2009) dalam penelitiannya dengan menggunakan pendekatan event study dengan analisis GARCH mengungkapkan bahwa krisis SARS 2003 membawa dampak negatif pada pariwisata dan sektor grosir dan retail. Hasil ini telah dikonfirmasi oleh banyak penelitian sebelumnya, tetapi memang demikian paling penting bahwa sektor bioteknologi mendapat guncangan positif dari dampak krisis SARS. Oleh karenanya, manajer investasi dan investor pada waktu itu banyak yang membeli dan menahan saham bioteknologi dan mengatur ulang portofolio mereka untuk memperoleh keuntungan investasi, mempertahankan return portofolio, atau risiko investasi yang lebih rendah selama periode wabah SARS di Taiwan.

Selanjutnya Chen et al (2018) menguji hubungan jangka panjang dampak SARS pada Bursa Saham Cina dan empat pasar saham Asia. Chen et al (2018) menggunakan kointegrasi varians untuk menguji hubungan antara pasar saham pasar tersebut. Hasil penelitian menunjukkan bahwa epidemi SARS melemahkan hubungan jangka panjang antara Bursa Saham China dan empat Bursa Saham Asia.

$\mathrm{Ru}$ et al (2020) menjelaskan reaksi pasar saham global terhadap wabah COVID-19 yang disebabkan oleh virus SARS-CoV-2. Pasar saham di negara-negara yang menderita penyakit SARS 2003 yang disebabkan oleh virus serupa (SARS-CoV-1) bereaksi lebih cepat dan kuat terhadap wabah COVID-19 pertama di Wuhan Cina selama akhir Januari 2020. Pola ini berlangsung selama bermingguminggu hingga sejumlah wabah di luar China (mis., Korea Selatan dan Italia) mulai parah pada akhir Februari, dan 
pasar saham di negara-negara tanpa pengalaman SARS mulai runtuh.

\section{METODE PENELITIAN}

Penelitian menggunakan metode event study dengan analisis Least Square Regression untuk menguji secara empiris adanya pengaruh wabah Corona (Covid-19) pada index harga saham LQ45, Consumer Goods, Manufacture dan Finance Bursa Efek Indonesia.

Sampel data penelitian diambil dari Bursa Efek Indonesia. Data yang diambil adalah Index LQ45, Index Consumer Goods, Index Manufacture dan Index Finance dengan variable endogen dalam penelitian yaitu harga saham dan likuditas saham, dengan dummy variable, dimana D2 = pengamatan 13 hari pertama di bulan April 2020. Kemudian D1 = 0 pengamatan 13 hari pertama di bulan April 2019.

\section{HASIL DAN PEMBAHASAN}

Data harga saham dan likuiditas saham Index LQ45, berdasarkan hasil penelitian yang diperoleh dari Bursa Efek Indonesia untuk periode 13 hari bursa April 2020 dibandingkan dengan 13 hari bursa April 2019, adalah sebagai berikut :

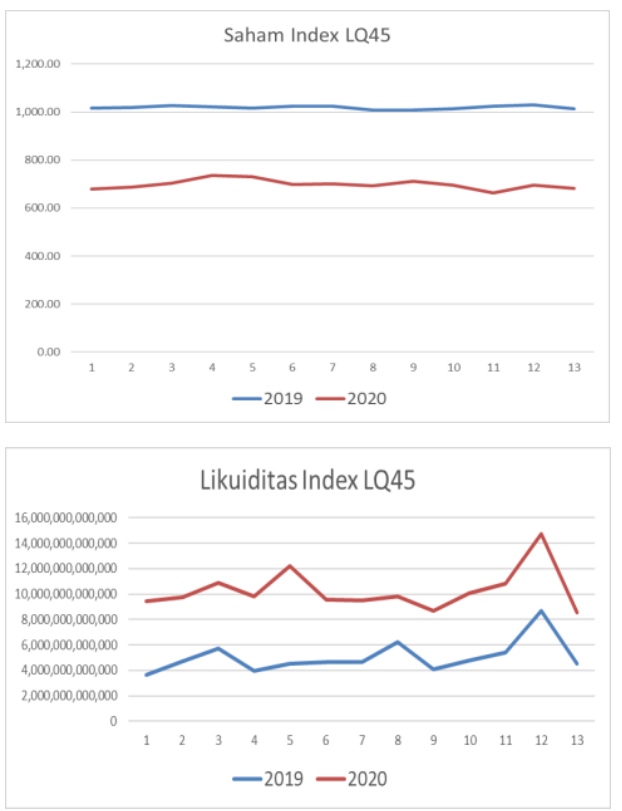

Data harga saham dan likuiditas saham Index Consumer Goods, berdasarkan hasil penelitian yang diperoleh dari Bursa Efek Indonesia untuk periode 13 hari bursa April 2020 dibandingkan dengan 13 hari bursa April 2019, adalah sebagai berikut :

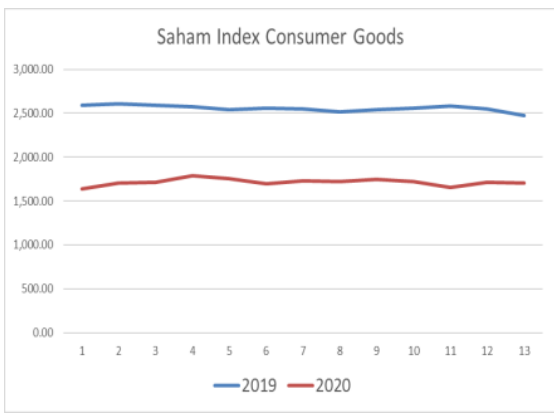




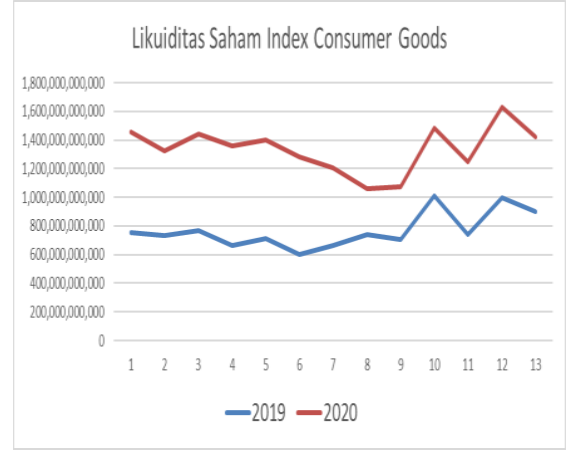

Data harga saham dan likuiditas saham Index Manufacture, berdasarkan hasil penelitian yang diperoleh dari Bursa Efek Indonesia untuk periode 13 hari bursa April 2020 dibandingkan dengan 13 hari bursa April 2019, adalah sebagai berikut :

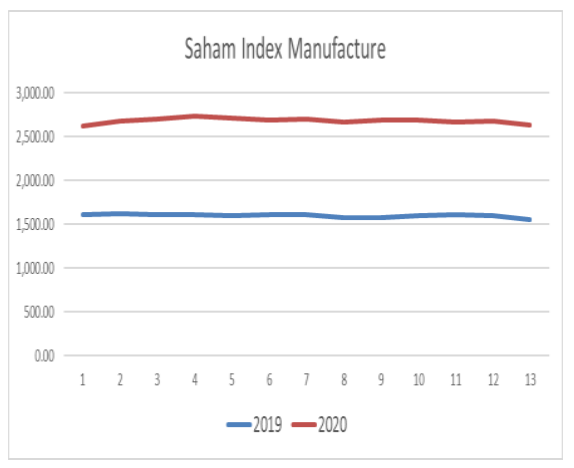

Likuiditas Saham Index Manufacture

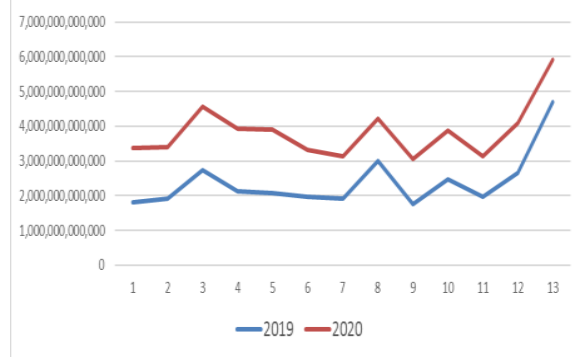

Data harga saham dan likuiditas saham Index Finance, berdasarkan hasil penelitian yang diperoleh dari Bursa Efek Indonesia untuk periode 13 hari bursa April 2020 dibandingkan dengan 13 hari bursa April 2019, adalah sebagai berikut
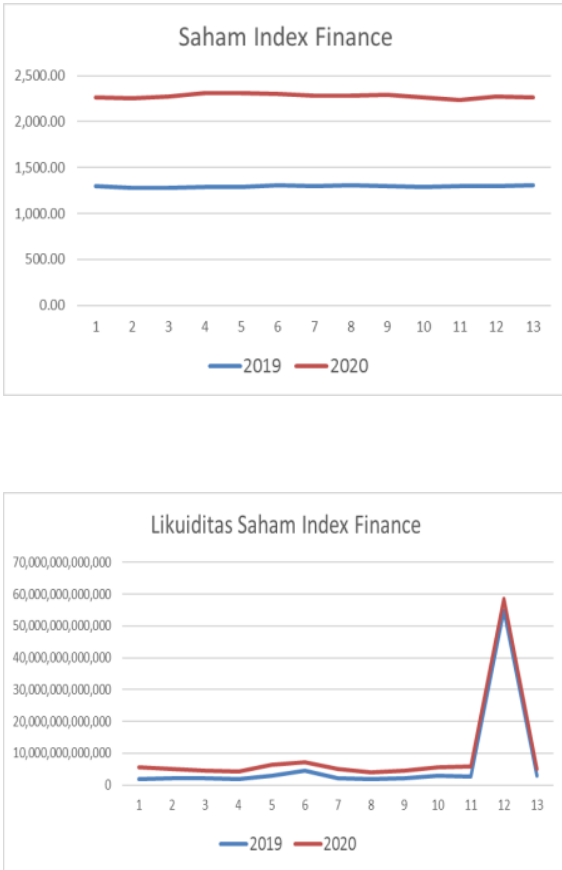

Untuk melihat dampak corona covid19 terhadap harga saham, peneliti mengolah data menggunakan Eviews dengan metode Least Square Regression.

\begin{tabular}{|l|r|r|r|r|}
\hline \multicolumn{5}{|c|}{ Dampak Covid-19 terhadap Harga Saham } \\
\hline & LQ45 & Consumer & Manufacture & Finance \\
\hline Coefficient & -320.687 & -840.9345 & -516.9338 & -312.5268 \\
\hline Std. Error & 5.84072 & 14.57174 & 9.61953 & 7.126455 \\
\hline t-Statistic & -54.9055 & -57.70995 & -53.73795 & -43.85446 \\
\hline Prob. & 0.0000 & 0.0000 & 0.0000 & 0.0000 \\
\hline significant & sig & sig & sig & sig \\
\hline
\end{tabular}


Berdasarkan temuan hasil penelitian dapat kita lihat bahwa dampak Corona Covid-19 terhadap harga saham dari empat index yang ada di Bursa Efek Indonesia semuanya berpengaruh negatif signifikan. Hal ini berarti bahwa selama 13 hari di awal bulan April 2020 terjadi penurunan harga saham yang signfikan dibandingkan dengan periode yang sama di tahun sebelumnya, akibat dampak dari adanya wabah corona covid-19. hasil temuan ini dapat dijadikan pertimbangan bagi investor agar lebih berhati-hati dan mencermati akan wabah seperti ini, karena berdampak terhadap penurunan harga saham.

Selanjutnya untuk melihat dampak corona covid-19 terhadap likuiditas saham, disajikan pada tabel berikut ini :

\begin{tabular}{|l|r|r|r|r|}
\hline \multicolumn{5}{|c|}{ Dampak Covid-19 terhadap Likuiditas Saham } \\
\hline & LQ45 & \multicolumn{1}{c|}{ Consumer } & Manufacture & Finance \\
\hline Coefficient & $2.05 \mathrm{E}+11$ & $-1.99 \mathrm{E}+11$ & $-9.41 \mathrm{E}+11$ & $-3.81 \mathrm{E}+12$ \\
\hline Std. Error & $4.60 \mathrm{E}+11$ & $4.99 \mathrm{E}+10$ & $2.31 \mathrm{E}+11$ & $4.04 \mathrm{E}+12$ \\
\hline t-Statistic & 0.44512 & -3.98331 & -4.068286 & -0.94229 \\
\hline Prob. & 0.6602 & 0.0005 & 0.0004 & 0.3554 \\
\hline significant & non sig & sig & sig & non sig \\
\hline
\end{tabular}

Berdasarkan temuan hasil penelitian dapat kita lihat bahwa dampak Corona Covid19 terhadap likuiditas saham dari empat index yang ada di Bursa Efek Indonesia, hanya terdapat 2 index berpengaruh negatif signifikan yaitu Index Consumer Goods dan Index Manufacture. Hal ini dapat dikatakan bahwa selama periode amatan 13 hari di awal bulan April 2020 dibandingkan dengan periode yang sama di tahun sebelumnya, terjadi penurunan likuiditas saham. Hal ini berarti juga bahwa terjadi kelesuan perdagangan saham dalam Index Consumer Goods dan Index Manufacture sebagai akibat dari wabah Corona Covid-19 yang terjadi di Indonesia.

Selanjutnya dampak Corona Covid19 pada Index LQ45 dan Index Finance tidak mempunyai pengaruh terhadap likuiditas saham. Bila kita perhatikan grafik likuiditas saham Index Saham LQ45 pada 13 hari di awal April 2020 dibandingkan dengan periode yang sama pada tahun sebelumnya, terjadi penurunan likuiditas. Namun penurunan likuiditas saham ini tidak signifikan sebagai akibat dari wabah Corona Covid-19. Hal ini bisa disebabkan oleh faktor lain diluar penelitian. Selain itu, bila kita perhatikan grafik likuiditas saham pada Index Finance, juga pada hasil regresi penelitian, terlihat bahwa terjadi penurunan likuiditas saham namun secara tidak bermakna sebagai akibat dari wabah Corona Covid-19. Fenomena ini bisa saja 
dipengaruhi oleh faktor lain diluar penelitian.

Secara umum berdasarkan 4 index yang ada di Bursa Efek Indonesia, wabah Corona Covid-19 berdampak negatif signifikan terhadap harga saham pada Index LQ45, Index Consumer Goods, Index Manufacture dan Index Finance. Hasil temuan ini dapat dijadikan pertimbangan bagi investor agar lebih berhati-hati dan mencermati akan wabah seperti ini, karena berdampak terhadap penurunan harga saham. Hasil temuan ini juga memperkuat beberapa penelitian terdahulu Nippani \& Washer (2004), Loh (2006), Chen et al (2007), Chen et al (2009), Chen et al (2018), $\mathrm{Ru}$ et al (2020).

Hasil penelitian tidak mutlak bahwa penyebab penurunan harga saham murni karena wabah Corona Covid-19. Masih ada faktor-faktor lain diluar penelitian yang masih perlu dibuktikan secara empiris. Penelitian ini juga mempunyai banyak kekurangan-kekurangan yang dapat dijadikan ide gagasan bagi penelitian selanjutnya. Kekurangan penelitian ini yaitu sampel penelitian yang sedikit, sampel diambil hanya 13 hari di awal April 2020 dan 13 hari di awal April 2019. Kekurangan berikutnya, peneliti hanya mengambil sampel pada 4 Index Saham yang ada di Bursa Efek Indonesia, sehingga perlu juga dikaji pada Index-Index Saham yang lain. Kemudian peneliti tebatas melakukan penelitian hanya di negara Indonesia saja, sedangkan wabah Corona Covid-19 juga terjadi di Asia, Eropa dan Amerika.

\section{KESIMPULAN DAN SARAN}

\section{A. Kesimpulan}

Berdasarkan hasil penelitian maka dapat disimpulkan bahwa selama 13 hari di awal April 2020 dibandingkan periode yang sama di tahun 2019. Terjadi penurunan harga saham yang secara signifkan akibat dari wabah Corona Covid-19 pada Index LQ45, Index Consumer Goods, Index Manufacture, serta Index Finance.

Kesimpulan selanjutnya yaitu terjadi penurunan Likuditas Saham secara signifikan pada Index Consumer Goods dan Index Manufacture sebagai akibat dari wabah Corona Covid-19 di Indonesia.

\section{B.Saran}

Investor perlu mencermati terjadinya peristiwa Corona Covid-19 dan mengantisipasi penurunan harga 
saham serta memperhatikan likuiditas saham. Perlu kajian yang lebih mendalam untuk penelitian selanjutnya, karena selain pengaruh dari Corona Covid-19, masih ada faktor-faktor lain yang dapat mempengaruhi harga saham dan likuiditas saham.

Perlu dikembangkan penelitian selanjutnya mengenai dampak wabah Corona Covid-19 terhadap harga saham dan likuiditas saham. Sebagai saran yaitu dengan menambah jumlah sampel penelitian, menambah jumlah Index Saham dan menambah jumlah negara untuk dijadikan sampel penelitian.

\section{DAFTAR PUSTAKA}

Fama, Eugene F. (1970). "Efficient Capital Markets: A Review of Theory and Empirical Work." The Journal of Finance, Vol. 25, No. 2, pp. 383-417,

Chen, Chun-Da \& Chen, Chin-Chun \& Tang, Wan-Wei \& Huang, Bor-Yi. (2009). "The Positive and Negative Impacts of the Sars Outbreak: A Case of the Taiwan Industries." Journal of Developing Areas - J DEVELOP AREAS. 43. 10.1353/jda.0.0041.
Chen, M.-P., Lee, C.-C., Lin, Y.-H., \& Chen, W.-Y. (2018). "Did the S.A.R.S. epidemic weaken the integration of Asian stock markets? Evidence from smooth time-varying cointegration analysis." Economic ResearchEkonomska Istraživanja, 31(1), 908-926.

Chen, M.-H., Jang, S. (Shawn), \& Kim, W. G. (2007). "The impact of the SARS outbreak on Taiwanese hotel stock performance: An eventstudy approach." International Journal of Hospitality Management, 26(1), 200-212.

Drakos, K. (2004). "Terrorism-induced structural shifts in financial risk: airline stocks in the aftermath of the September 11th terror attacks." European Journal of Political Economy, 20(2), 435-446..

Loh, Elaine. "The Impact Of Sars On The Performance And Risk Profile Of Airline Stocks." International Journal of Transport Economics / Rivista Internazionale Di Economia Dei Trasporti 33, no. 3 (2006): 401-22.

Nippani, S., \& Washer, K. M. (2004). "SARS: A non-event for affected countries' stock markets?" Applied Financial Economics, 14(15), 1105-1110

Oktrima, B., \& Riani, N. (2019). PENGARUH PERPUTARAN KAS DAN PERPUTARAN PIUTANG TERHADAP RETURN ON INVESTMENT (ROI) PADA PT. SEMEN INDONESIA (PERSERO) TBK PERIODE TAHUN 2008-2017. Jurnal Ekonomi Efektif, 2(1). 
Purnomo, S., \& Pasaribu, V. L. D. (2019). Pergerakan Harga Saham Pt Adaro Energy Tbk (Adro) Pada Pengumuman Dividen Interim Tahun Buku 2018. Jurnal Ekonomi Efektif, 2(1).

$\mathrm{Ru}$, Hong and Yang, Endong and Zou, Kunru. (2020). "What Do We Learn from SARS-CoV-1 to SARS-CoV-2: Evidence from Global Stock Markets" SSRN Electornic Journal.

Utama, Cynthia Afriani \& Hapsari, Lina (2012). "Jenis Industri, Kepemilikan Saham Asing Dan Reaksi Pasar Modal Akibat Serangan Bom Teroris." Jurnal Akuntansi dan Keuangan Indonesia, Desember 2012, Vol. 9, No. 2, hal $100-116$.

Virby, S. (2020). PENGARUH CURRENT RATIO (CR) DAN DEBT TO ASSETS RATIO (DAR) TERHADAP RETURN ON ASSETS (ROA)(Studi Kasus pada PT. Electronic City Tbk yang Terdaftar Di Bursa Efek Indonesia Tahun 20082017). JURNAL SeMaRaK, 3(1), 126-155.

Virby, S., \& Lidia, E. (2019). ANALISIS PEN, GARUH "PERPUTARAN "K; AS DAN CURRENT RASIO TERHADA, $P$ RETURN ON ASSET DI PT. ULTR, AJAYA MIILK INDUST, RY AND TR, ADING COOMPANY, TBK PERIIODE TAHUN 2008-2017. Jurnal

Semarak, 2(3), 161-170.

Virby, S. (2017). Pengaruh Indeks Dow Jones Industrial Average, Nikkei 225, Hangseng Index, dan Shanghai Stock Exchange terhadap Indeks Harga Saham Gabungan Bursa Efek Indonesia Periode Tahun 2008-2013. INOVASI, 4(2). 